\title{
Developing Value Innovation Strategy In The "Blue Ocean Shift" Framework At The Flat Glass Industry In Indonesia
}

\author{
Rudy Subagio* \\ Airlangga University, Surabaya, Indonesia
}

\begin{abstract}
Competition in the flat glass market in Indonesia since 2015 has been increasingly severe because much imported glass has entered Indonesia. The rapid rate of imported glass is due to two factors: the enactment of the free trade pact in Southeast Asia and the expansion of the Chinese glass factory that built new factories in the Southeast Asia region, especially in Malaysia. Most of the imported glass entering Indonesia is commodity glass at a lower than local products, so they have begun to take a portion of the market share of local products. This competition is getting more onerous because the local flat glass industry has difficulties in reducing the price to be equal or lower than competitors' price due to the production cost structure is already too high. This research explores the basic concepts of strategies carried out by local flat glass companies in the face of competition in the flat glass industry. This is based on the concept of value innovation in the framework of "blue ocean shift." The research method used is an exploratory case study draws on an in-depth field study conducted in a local flat glass company based in Indonesia.
\end{abstract}

Keywords: Value Innovation; flat glass industry; Blue Ocean Shift

\section{Introduction}

The Indonesian flat glass industry began to be built in 1971 and began commercial production in 1973. Building a flat glass factory at that time was to reduce dependence on imported glass. The growth of the glass industry in Indonesia reached its best in the 2000s, at that time there were 5 players in the domestic flat glass industry. The flat glass industry has grown along with the economic growth in Indonesia. Increasing competition in the domestic flat glass industry has caused domestic flat glass industry players to drop and leaving only two players who have survived since 2017. This intense competition is caused by the entry of imported glass from China at lower prices in recent years.

In general, the flat glass industry's business environment condition can be seen from the flat glass market transactions throughout the world. In 2015 the global market demand for flat glass was around 73.2 million metric tons ( 9.3 billion square meters), with a market value equivalent to 35 billion US dollars (USD). This market has grown around 4 to 5 percent a year.

\footnotetext{
* Corresponding email: rudy.subagio@gmail.com
} 


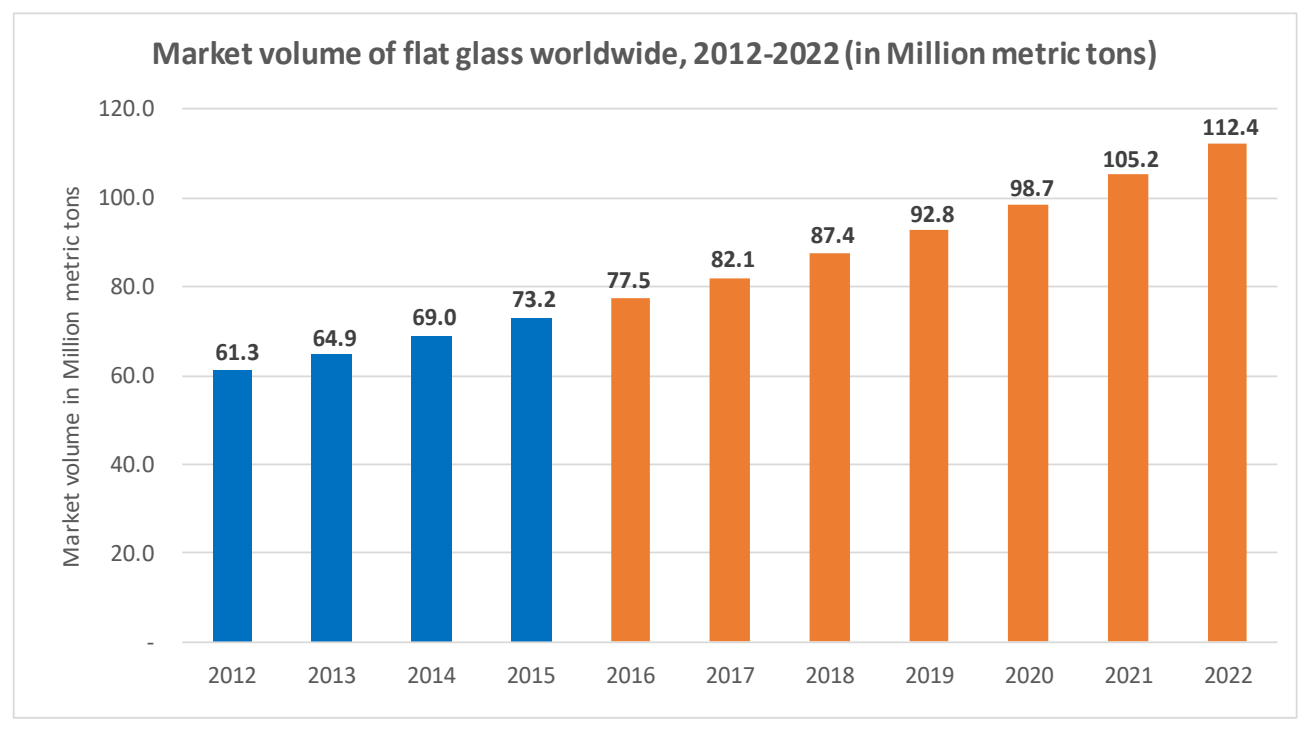

Figure 1. The Trend of Flat Glass market volume 2012 - 2022

(Statista.com, 2015)

China is the largest producer of glass and glass products, producing more than 50 percent of the global output of flat glass. China has the most significant number of flat glass factories in the world. The growth of flat glass factories in China began to increase rapidly around the 2000s. During 20012011, the number of float lines in China has increased nearly three times as well as the total production increased from 12 million tons to 35 million tons in 10 years (NSG Groups, 2010). The rapid growth of the flat glass industry in China has push them to export their product to Southeast Asian region, including to Indonesia.

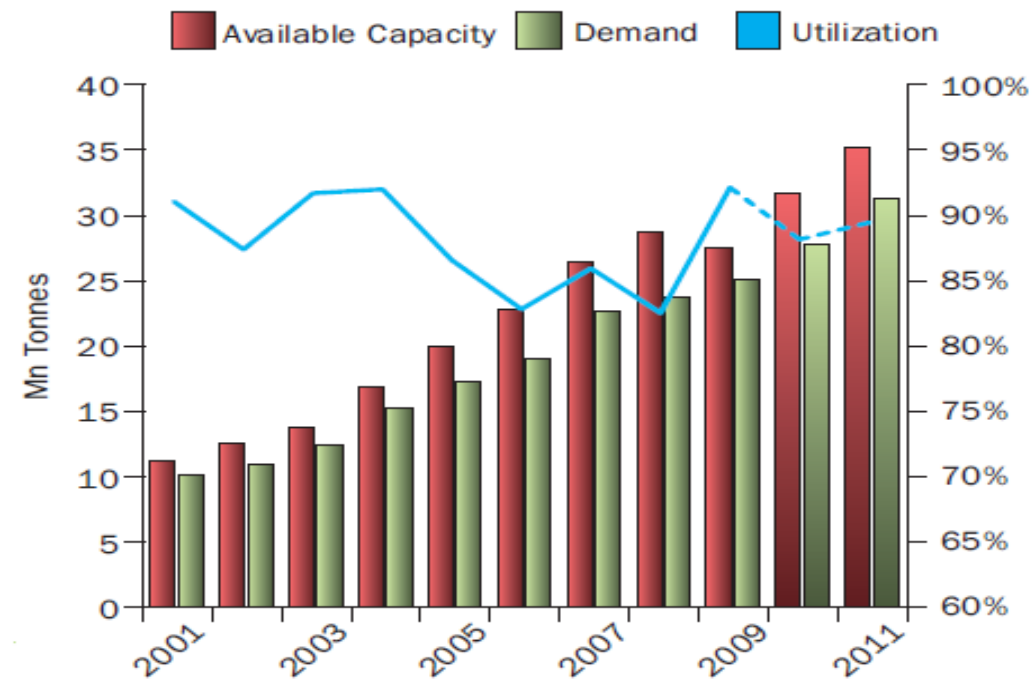

Figure 2. Total Flat Glass Production of China 2001-2011

(NSG Group, 2010)

From 2012 until 2015, the Chinese flat glass industry has begun to increase its pressure on the flat glass market in the ASEAN region by directly exporting its product. However, starting in 2016, the 
Chinese flat glass factory began to expand by building a factory in Malaysia. In 2016, Xinyi and Kibing, big players in the flat glass industry in China, built a flat glass factory in Malaysia and started to export their products to Indonesia. In total, imported glass from Chinese manufacturers in China and Malaysia increased rapidly during 2015 - 2018. During this period volume of imported glass increase almost seven times from 18.6-kilo tons in 2015 to be 128.2-kilo tons in 2018. Since 2017, factories in Malaysia had begun operated at full capacity, and they had been taking over the shipment of glass, which is sent directly from factories in China.

Table 1. Total Imported Flat Glass from China and Malaysia (unit: Kilo Tons)

\begin{tabular}{lcccc}
\hline & 2015 & 2016 & 2017 & 2018 \\
\hline China & 17.5 & 33.2 & 74.7 & 27.4 \\
Malaysia & 1.1 & 1.1 & 30.4 & 100.8 \\
\hline Total & 18.6 & 34.3 & 105.1 & 128.2 \\
\hline \multicolumn{5}{c}{ (UN-Comtrade Database, 2019) }
\end{tabular}

According to the Indonesian Flat and Safety Glass Association (AKLP), the total capacity of Flat Glass Industry in Indonesia is around 1,300-kilo tons per year, while total demand only 800-kilo tons per year (AKLP, 2019). The over capacity around 500-kilo tons is intented for export.

Since China glass manufacturers had built the new factory in Malaysia, the volume of Indonesia's flat glass exports to Malaysia during 2015 - 2018 decreased significantly. The total volume of Indonesia's flat glass export globally also decreased. The decline in export volume caused excess production to be sold in the domestic market, thereby causing more competition in the domestic market.

Table 2. Indonesia's Flat Glass Export Volume (unit: Kilo Tons)

\begin{tabular}{lcccc}
\hline Destination & $\mathbf{2 0 1 5}$ & $\mathbf{2 0 1 6}$ & $\mathbf{2 0 1 7}$ & $\mathbf{2 0 1 8}$ \\
\hline All the World & 472.6 & 443.1 & 396.9 & 385.8 \\
Malaysia & 115.7 & 91.1 & 44.5 & 43.7 \\
\hline
\end{tabular}

(UN-Comtrade Database, 2019)

The extremely tight competition conditions in the flat glass industry, as described above, can be described as Red Ocean competition (Kim \& Mauborgne, 2005), where many players compete in the same market space, making competition very tight and bloody.

The competition faced by the domestic flat glass industry due to the entry of imported glass from Chinese manufacturers into the domestic market will threaten the survival of the flat glass industry in Indonesia today and in the future. To deal with this threat requires a a beneficial and proven effective strategy such as a strategy based on value innovation concept developed through Blue Ocean Shift strategy. This study questions on how does the flat glass company in Indonesia develop a strategy in dealing with competition against cheaper imported glass based on the concept of "value innovation" within the framework of "shifting the Blue Ocean"?

\section{The Concept of Strategy and Business Strategy}

In the most general sense, the strategy aims to enable the company to create value for customers and build a stronger market position by considering a changing environment (Semples \& Hoffman, 2013). More specifically, corporate strategy is a focus on achieving specific goals, which involves the allocation 
of resources, which is carried out through a series of actions and decisions that are consistent, integrated, and cohesive (Grant, 2016).

There are several important factors that we must consider in implementing a strategy, according to Grant (2016), the factors that influence the success of a strategy are as follows:

1. Consistent and long-term goals

2. A deep understanding of the competitive environment situation

3. An objective assessment of the resources owned

4. Effective implementation

\section{Implementation of Strategies in Organizations}

According to Kearney (2014), the most important thing for organizations to implement strategies is to change the overall strategy from an imperfect action plan into comprehensive organizational energy. There are 3 steps that must be taken to achieve that goal:

1. Shift strategy formulation from current-out to future-in

2. Shift the strategy process from cascading down to organizational inclusive

3. Do not aim for a single strategy but an ongoing portfolio of competitive advantages

To understand whether the strategy being implemented is valid or not or to assess the success of a strategy, a strategy must be measurable. One way to assess whether a strategy is truly efficient, effective, and in harmony with the mission and long-term goals is by the Rumelt method (Rumelt, 1998), based on four criteria:

1. Consistency: Goals and policies are mutually consistent.

2. Conformity: Easily adapts to changes in the environment.

3. Excellence: Provides a competitive advantage.

4. Feasibility: Can be done with existing resources.

\section{Innovation}

Innovation is the most significant engine that fuels growth for the individual, for the organization, or the nation as a whole. According to Gaynor (2002), innovation as a management field requires methodology in managing and controlling limited resources. In the context of the organization, innovation requires a systematic approach to managing and optimizing an organization's resources. Innovation is about people and processes. It needs to be built an innovative attitude and culture that encourages innovation at all levels of the organization. Innovation needs to be supported by adequate resources and supporting infrastructure.

Implementing a type of innovation that best fits the company's current business model and the company's technical (technological) capabilities can also refer to the innovation landscape map matrix below. The selection of the right type of innovation will determine the company's success in the present and the future (Pisano, 2015). 


\begin{tabular}{|c|c|c|}
\hline \multirow{4}{*}{$\begin{array}{l}\text { REQUIRES } \\
\text { NEW } \\
\text { BUSINESS } \\
\text { MODEL }\end{array}$} & DISRUPTIVE & ARCHITECTURAL \\
\hline & $\begin{array}{l}\text { - Open source software } \\
\text { FOR SOFTWARE COMPANIES }\end{array}$ & $\begin{array}{l}\text { - Personalized medicine } \\
\text { FOR PHARMACEUTICAL COMPANIES }\end{array}$ \\
\hline & $\begin{array}{l}\text { - Video on demand } \\
\text { FOR DVD RENTAL SERVICES }\end{array}$ & $\begin{array}{l}\text { - Digital imaging } \\
\text { FOR POLAROID AND KODAK }\end{array}$ \\
\hline & $\begin{array}{l}\text { - Ride-sharing services } \\
\text { FOR TAXI AND LIMO COMPANIES }\end{array}$ & $\begin{array}{l}\text { - Internet search } \\
\text { FOR NEWSPAPERS }\end{array}$ \\
\hline \multirow{5}{*}{$\begin{array}{l}\text { LEVERAGES } \\
\text { EXISTING } \\
\text { BUSINESS } \\
\text { MODEL }\end{array}$} & ROUTINE & RADICAL \\
\hline & $\begin{array}{l}\text { - A next-generation } 3 \text { series } \\
\text { FOR BMW }\end{array}$ & $\begin{array}{l}\text { - Biotechnology } \\
\text { FOR PHARMACEUTICAL COMPANIES }\end{array}$ \\
\hline & $\begin{array}{l}\text { - A new index fund } \\
\text { FOR VANGUARD }\end{array}$ & $\begin{array}{l}\text { - Jet engines } \\
\text { FOR AIRCRAFT MANUFACTURERS }\end{array}$ \\
\hline & $\begin{array}{l}\text { - A new 3-D animated film } \\
\text { FOR PIXAR }\end{array}$ & $\begin{array}{l}\text { - Fiber-optic cable } \\
\text { FOR TELECOMMUNICATIONS COMPANIES }\end{array}$ \\
\hline & $\begin{array}{l}\text { LEVERAGES EXISTING } \\
\text { TECHNICAL COMPETENCES }\end{array}$ & $\begin{array}{l}\text { REQUIRES NEW } \\
\text { TECHNICAL COMPETENCES }\end{array}$ \\
\hline
\end{tabular}

Figure 3. The Innovation Landscape Map

(Pisano, 2015 )

\section{Value Innovation}

The concept of "Value Innovation" is one of a themes in the strategy field that has developed rapidly in the last two decades. According to Leavy (2018), The Value Innovation has three main variations in its application :

1. Blue Ocean Strategy (Kim \& Mauborgne, 2005)

2. Disruption Innovation (Christensen et al., 2003)

3. Co-creation Value (Prahalad \& Ramaswamy, 2004)

All three have some common characteristics in distinguishing the perspective of value innovation from the usual approach taken today, including:

a) Viewing the primary strategy challenge as to how to create and capture new demand.

b) Shifting the primary emphasis in strategy development back onto the customer rather than the competition.

c) Recognizing significant new demand potential in current "non-consumption" and ways to overcome it.

d) Aiming for a "value breakthrough" (or leap in value), usually through business model innovation - changing the game.

Where:

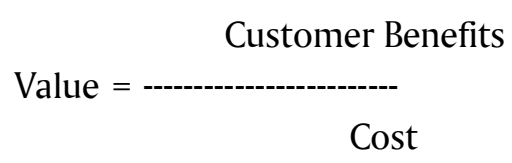

However. The three variations of the above approach have differences in highlighting new types of market space opportunities, as explained below:

1. The Blue Ocean Strategy tends to focus on value innovations that ultimately uncover new demands/markets by redefining the categories of values that customers want, such as Cirque de Soleil - entertainment that combines circus and theater.

2. Disruption Innovations tend to concentrate on creating new demand that expands the markets currently served, such as Southwest and Ryanair in the low-cost air travel business. 
3. Co-creation Value create new demand by transforming user experience, offering "personalization that can be scaled" through the use of smart connected technologies. It turns traditional products into platforms interactive, information, involvement, as did Nike with "Nike smart wearables" and LEGO with its robot toys.

\section{The Innovation of Values and Blue Ocean Strategy}

According to Kim and Mauborgne (2005), The Blue Ocean Strategy was built on the concept of value innovation. Blue oceans are described as a market that has not yet been created. Significant new and indisputable new demand is created by companies that are willing and able to pursue "strategic steps." Value innovation in the blue ocean strategy is carried out by reconfiguring value propositions in new ways that force quantum leaps beyond the limits of current red ocean costs by increasing buyer value and simultaneously reducing company costs. The emphasis on value and innovation is crucial for creating a new "blue ocean" market space.

The blue ocean strategy outlines the conceptual differences and underlying patterns between "red oceans" that compete in existing markets and "blue oceans" that create markets (Kim \& Mauborgne, 2005). Kim and Mauborgne also provide the primary analysis tools for creating blue oceans, namely:

1) Canvas Strategy and Value Curve

2) The Framework for the Four Actions and the ERRC Matrix

3) Six Pathways to reconstruct Market Boundaries

4) Map of "Pioneer-Migrator-Settler"

5) Three Non-Consumer Levels

6) Utility-Buyer Map

7) Three Characteristics of a Good Blue Ocean Strategy

\section{Implement a Successful Blue Ocean Shift}

The essence of the Blue Ocean shift is to set new market boundaries by breaking down existing market boundaries and rebuilding new market boundaries to create a new front-line cost-value (Kim \& Maugborne, 2017). Kim \& Maugborgne also analyzed and compared how organizations implement blue oceans shift. They come to conclusions about what are the common factors that lead to successful blue ocean shifts. It can be summarized in the following three main components as follow:

1. Adopt a blue ocean perspective

A significant change in mindset from the "red ocean" to the "blue ocean" strategic thinking needs to be careful to avoid the most common cognitive "trap" of the red ocean.

2. A set of tools for creating markets

The tool is used the same as in the Blue Ocean Strategy with further guidance on how to apply it as an inseparable part of the blue ocean "transformation journey."

3. Having a "humanistic process."

Successful blue ocean shifts are also characterized by a process that inherently "recognizes people, acknowledges their fears, their insecurities, their need to be treated with dignity, their desire to care. 


\section{A Systematic Five-Step Process}

In Blue Ocean Shift, Kim and Mauborgne (2017), describe the three essential components above into a systematic five-step process to help organizations develop and implement successful new market creation strategies. The five steps are:

1. Getting Started

2. Understand where you are now.

3. Imagine where you can be.

4. Find a way to get there.

5. Make a move

\section{Methodology}

The research method used is an exploratory case study. This research was compiled based on an indepth study in one organization (single study case). The purpose of this study is to explore the current competitive environment in the domestic glass industry and choose the most appropriate strategy to answer these challenges. The case study was carried out in one of the largest and first flat glass industries in Indonesia. In order to preserve the firm's confidentiality, we will refer to it during this study with the fictitious name "Alpha Glass." Alpha Glass is a pioneer of the flat glass industry in Indonesia, and it represents domestic flat glass industries due to its most significant capacity and market share.

The research was conducted in the period 2018 - 2019, which was the most challenging time for the domestic flat glass industry facing competition with imported glass products from China. Since 2016, the Chinese flat glass industry began to expand massively by establishing a flat glass factory in Malaysia.

Primary data in this study were collected from interviews with top management teams of the organization consisting of General Managers, Factory Managers, Production Managers, and Sales \& Marketing Managers. They were directly involved in the development and implementation of the strategy. There were four semi-structured interviews conducted with those where the initial list of questions has been prepared, but on the way it can be adjusted based on the response at that time. The results of the interview are documented in the form of interview transcripts, and to maintain the anonymity of the interviewees, they are referred to as Senior Manager 1, Senior Manager 2, and more.

Data from interviews would be verified against data from observations and company documents or secondary data. Secondary data is collected from corporate documents in the form of strategic (business policy) documents and general company documents. Besides, secondary data regarding competition situation in the domestic glass industry is also obtained from the mass media, both print and electronic, internet and archive data, or database files from the Central Statistics Agency (BPS) and the Indonesian Association of Flat and Safety Glass (AKLP).

Based on the interview result, we identified the basic concepts of the strategies applied by Alpha Glass; then, they compared with the concept of value innovation within the framework of the Blue Ocean Strategy. This research explores the basic concepts of strategy that Alpha Glass uses in dealing with competition in the flat glass industry in the context of value innovation and a blue ocean shift.

\section{Results and Discussion}

The current competition in the domestic flat glass markets is very severe. If the price war continues, then the flat glass industries in Indonesia will not survive because its existing production 
cost structure is already high. This current situation also considered by Alpha Glass management as follows:

The current condition of domestic flat glass competition is burdensome, not only because of import products from China but producers from China are currently building factories in Indonesia, one of which is Bintang Float Glass, which will start operating in 2021. Besides, competition among local players is getting tighter because they cannot sell glass to the Southeast Asian region. They cannot compete with Chinese flat glass manufacturers, so they are more focused on competing domestically (Senior Manager-1)

In the domestic flat glass industry competition, Alpha Glass has only one local big competitor, but beside the local players, other competitors also coming from imported glass. Imported glass mainly coming from China manufacturer. The China flat glass manufacturer such as Kibing and Xinyi had built flat glass factories in Malaysia with huge capacity. Their products are intended to meet domestic demand in Malaysia and to be exported to neighboring countries in the Southeast Asia region including Indonesia (Senior Manager - 2)

The main reason for the severe competition is the entry of imported glass from Chinese glass producers, which built its factory in Malaysia at a meager price. Another reason is over-supply in the domestic market because the local producers can not sell their products to the Southeast Asian region. Shortly competition will be more severe because the Chinese flat glass factory also began to build a new factory in Indonesia. It might start to produce in 2021. Another factor that also influences is the application of free trade agreements in the Southeast Asia region.

The above conditions faced by Alpha Glass, according to Kim \& Mauborgne (2005), Alpha Glass must immediately shift to the Blue Ocean. Currently, Alpha Glass does not implement the Blue Ocean strategy, but what has been done by Alpha Glass is compatible with the Blue Ocean Strategy. This research aims to formulate a strategic framework of "value innovation" from the perspective of "Blue Ocean Shift" for Alpha Glass.

\section{The Five Steps to Making a Blue Ocean Shift}

The five steps to making a blue ocean shift provide structure and analytic guidance for the Alpha Glass to moves step-by-step to the blue ocean.

\section{Get Started}

The first step in the Blue Ocean shift initiative is to understand the company's current position. The company's current portfolio position as depicted on the "Pioneer-Migrator-Settler" Map. Commodity glass products as below explanation still dominate the current position of the Alpha Glass portfolio:

Currently, generic products or commodity glass still contribute to the most significant sales, even though the margins are continuously reduced due to competition from China's imported glass (Senior Manager - 1)

Currently, the portfolio composition for flat glass products is $45 \%$ VAP and $55 \%$ commodity glass, but slowly this will continue to shift because Alpha-Glass will focus on VAP as the main product while commodity glass is only a byproduct of excess product... (Senior Manager - 2) 
Currently the composition of the portfolio consists of commodity glass around $55 \%$ and glass with added value (VAP) around $45 \%$.

Table 3. Product Category vs Sales Revenue of Alpha Glass

\begin{tabular}{clccc}
\hline \multirow{2}{*}{ Product Category } & \multicolumn{1}{c}{ Kind of Glass } & Code & Sales Revenue & $\%$ \\
& & & & \\
\hline Commodity & Clear Glass & FL & $19 \%$ & $55 \%$ \\
& Dark Grey & DG & $23 \%$ & \\
& Tinted+others & Tint. & $13 \%$ & \\
& & & & \\
Value Added Product & Automotive & Auto & $17 \%$ & $45 \%$ \\
& Stopsol & SS & $11 \%$ & \\
& Sunergy & SN & $9 \%$ & \\
& Planible-G & PN & $0 \%$ & \\
& Mirror & Mi & $5 \%$ & \\
& Lacobel & LC & $1 \%$ & \\
& T-Sunlux & T-SLX & $2 \%$ & \\
\hline & \multicolumn{2}{c}{ (Author's compilation) } & &
\end{tabular}

In the next five years, this composition will change drastically to 70\% VAP glass and 30\% nonVAP. In the future, the non-VAP glass will only be an excess or a by-product, and VAP glass will be the main product.

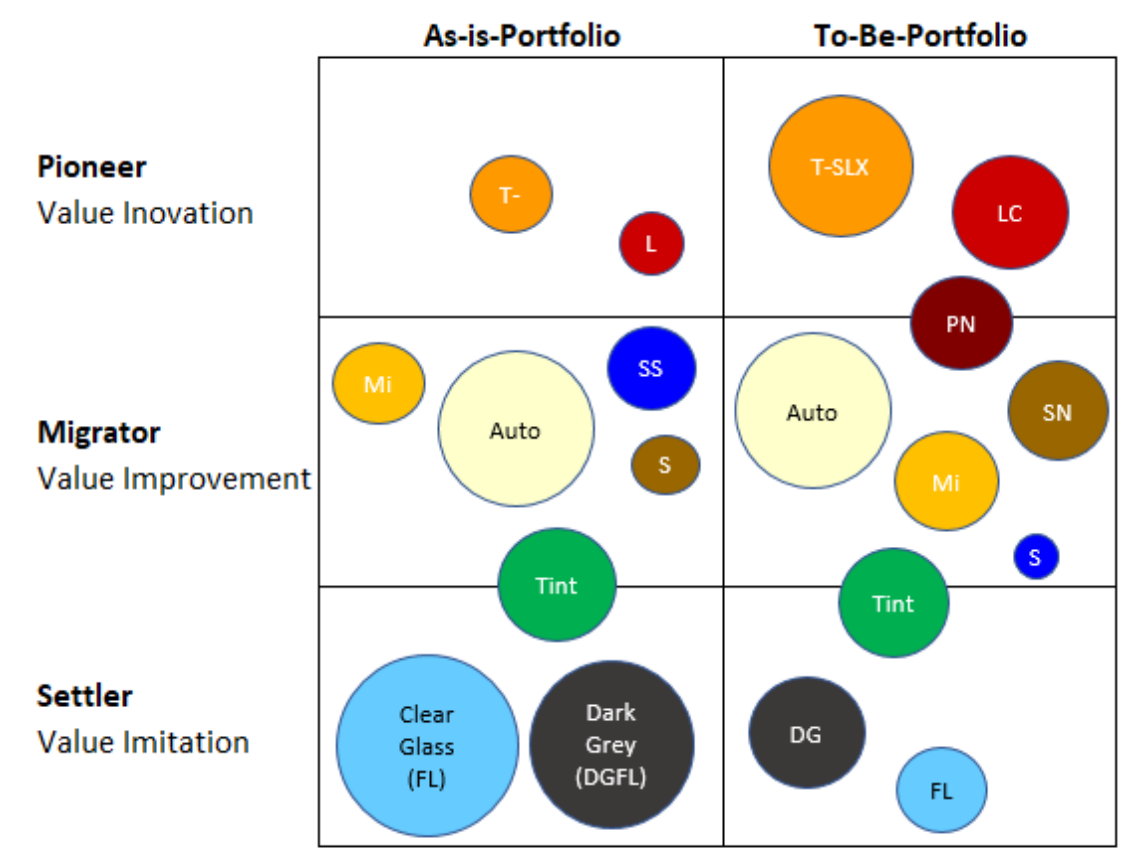

Figure 5. The "Pioneer-Migrator-Settler" maps of Alpha Glass

(Author's compilation) 


\section{Understand the Company's Current Position}

The second step aims to understand the company's position in the current competition in the flat glass industry. Alpha Glass's position on the competition map according to the management is as follow :

Alpha-glass is currently a market leader in both the Flat Glass market and the Automotive Glass market. It is currently still the leading player in the flat glass industry in Indonesia... (Senior Manager - 2)

The company is currently the market leader in Indonesia, even for Dark Gray glass currently controls around $70 \%$ of the domestic market share compared to its closest competitor, local glass producer. However, the market share is declining because of the entry of imported glass from China, whose prices are lower...(Senior Manager - 3)

Based on the above situation, it can be concluded that the position of Alpha Glass is still dominant as the market leader in the domestic flat glass market. However, competition conditions are getting more robust because the main competitors, both local and imported glass, are increasingly aggressive entering the market by offering lower prices; this condition leads to the price war. Currently, the Alpha Glass price offering is higher than its competitors due to high production costs, so if the price war continues, then the Alpha glass will not last.

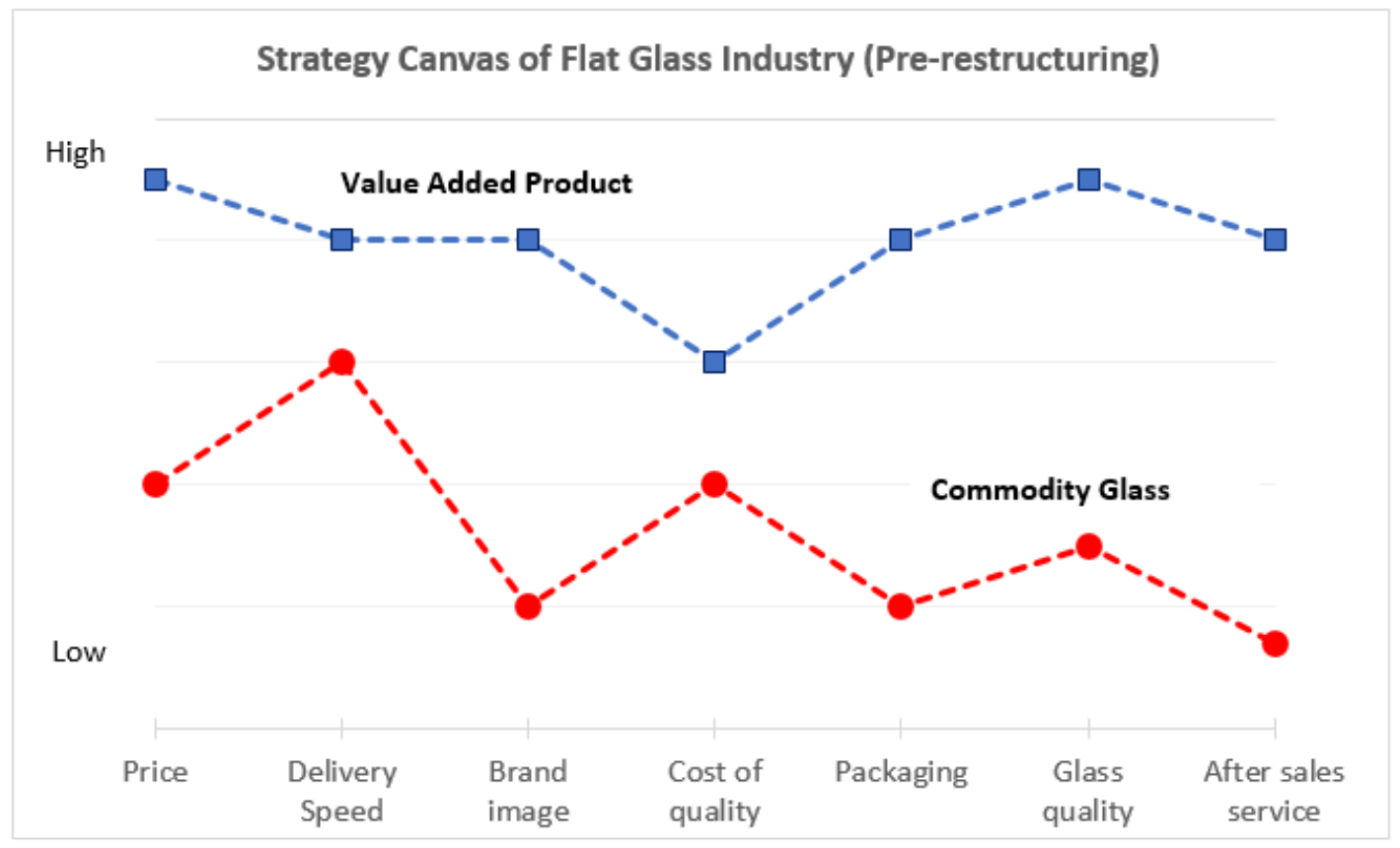

Figure 6. Strategy Canvas of Flat Glass Industry

(Author's compilation)

The whole picture of the competition faced by Alpha Glass can be seen more clearly and thoroughly in the above strategy canvas. The Factors contested in the domestic flat glass industry illustrated on the strategy canvas is as follow :

1. Price: Price of the commodity glass is very low compare with Value Added Glass (VAP), but shortly VAP will soon become a commodity product.

2. Delivery speed: on-time delivery is a significant factor because mostly the glass must be processed before installation on the building and to match with the deadline of the project. 
3. Brand Image: it is related to Alpha Glass's reputation for providing consistently high-quality products in the long run and fast response in responding to customer complaints regarding glass quality.

4. Cost of Quality: It consists of internal cost of quality, such as eliminating reject/No-Good product and waste and the external quality cost such as claim and complaint from customers.

5. Packaging: packaging has a function as safety to protect the glass inside and for the operator during handling. Besides that, they also express the visual performance of the product.

6. Glass quality: the quality of the glass substance, such as bubble, impurities, and visual transmission, is crucial during use. This is an essential requirement for high-quality float glass.

7. After Sales Services: handling claims and complaints from customers focused on how to respond to them and compensate claims in fast and straightforward way.

\section{Describe the company's position that can be achieved}

The position of Alpha Glass in the glass industry in the future can be describe in two action. The first is to reveal the "hidden pain points" that limit the current growth of Alpha Glass, and the second is to find non-consumer Oceans.

Hidden pain points can be revealed from the "buyer utility map," generally for the Glass Industry some hidden pain point are :

1. Price: the glass material is quite expensive compare with other transparent material such as polyurethane and some plastics.

2. Delivery time: mostly flat glass must be fabricated before use for building/windows or Automotive glass. Delivery time become a more critical factor.

3. Weight: glass seems light due to visually it is transparent but heavy

4. Fragile: easy to breakage

5. Not easy to decompose: glass is tough to decompose, it should be recycled

Besides "pain point," there are some excellent properties of glass, such as "durability" and "luxury image," where Flat Glass Industry focuses on. In this case, Alpha Glass focuses on creating new attractive products while pursuing cost reduction and improving on-time delivery.

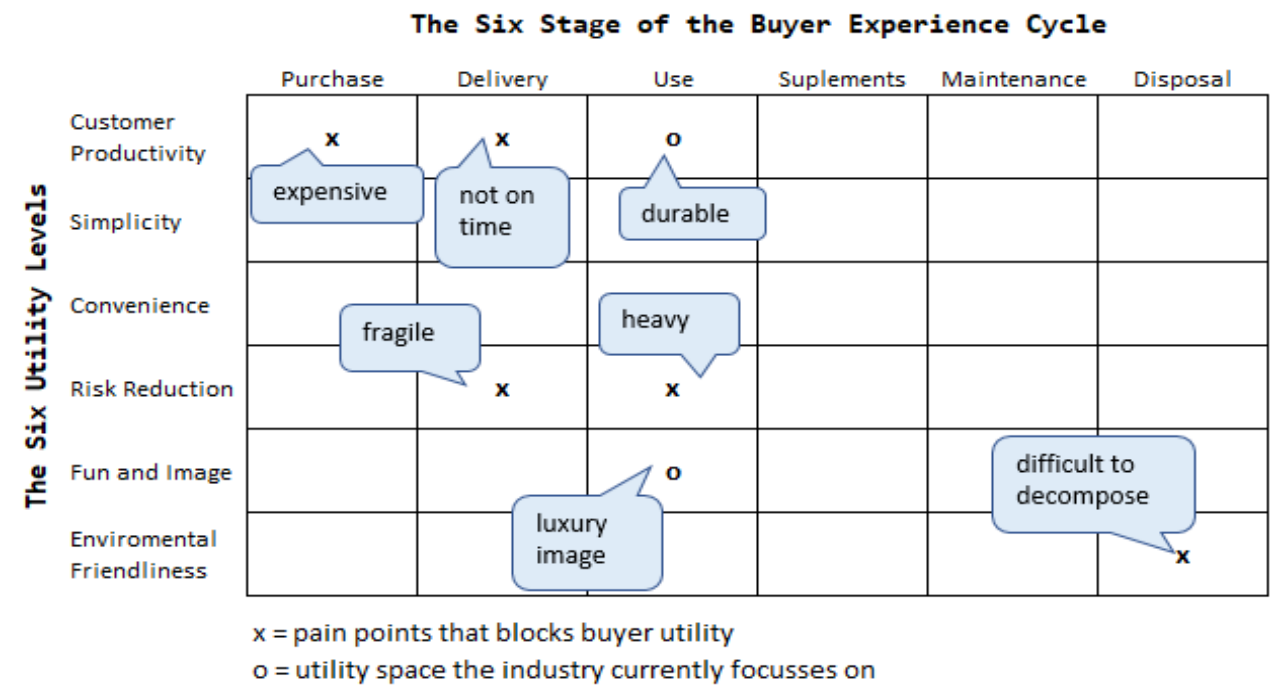

Figure 7. Buyer Utility Map of Alpha Glass

(source: Author's compilation) 
The next step to unlock new demand in the future is for Alpha Glass to identify "The Three Tiers of Non-Customers" in the flat glass industry.

\section{The Three Tiers of Non-Customers of the Flat Glass Industry}

First Tier of Non-customers: Developers who use glass as the roof of a building, a car garage, or to replace the walls of a room. They use glass minimally because the shortcomings of glass material are fragile and bulky.

Second Tier of Non-customers : The furniture manufacturer who use wood or steel for making the furniture. They never thougt that flat glass can be used as raw material for making furniture. They refuse to use the glass due to substitution material is cheaper and available.

Third Tier of Non-customers: The Telecommunication companies which use WiFi-antennas as separated electronic devices that applied inside the building or car. In the future, the glass have an integrated function as WiFi-antennas. Applying this glass in building or car will eliminate using dedicated device of WiFi antennas.

\section{What the Company Must do to Realize Its Goals}

This step is implementing the company's strategy to achieve company goals, by shifts the process to "generating the practical, real-world, blue ocean options." The two main tasks involved in this step are:

1. Systematically reconstructing market boundaries.

2. Developing alternative blue ocean opportunities.

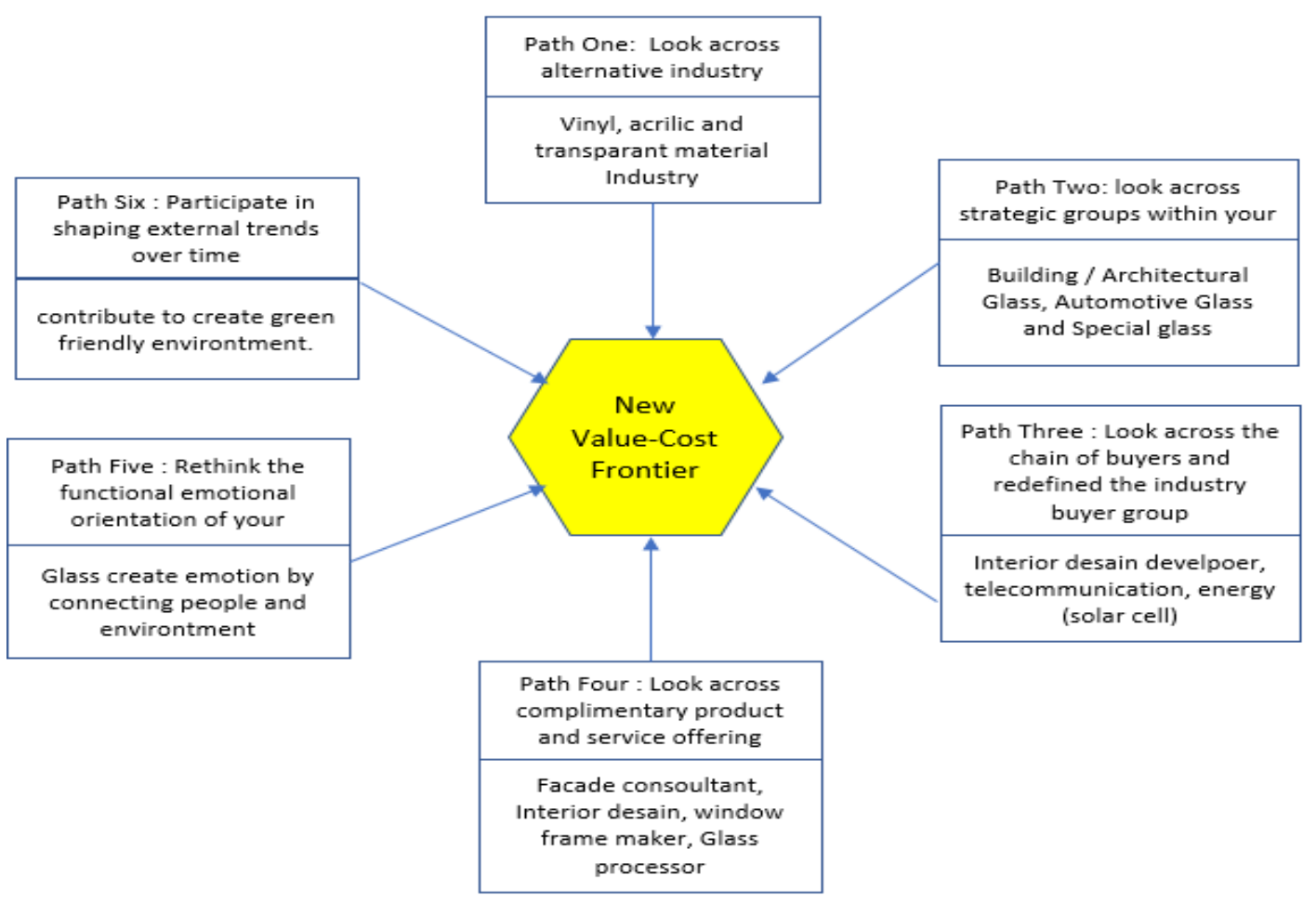

Figure 8. Reconstruct Market Boundaries of Alpha Glass

(Author's compilation)

To reconstruct market boundaries means companies must set new market boundaries to create a new front-line cost-value, using analysis tools of six paths framework (Kim \& Mauborgne, 2017). 
The next step is developing alternative blue ocean opportunities using the "Four Actions Framework" built around a set of four questions: what factors can be eliminated, reduced, raised, and created. It can be summarized on the ERRC (Eliminate-Reduce-Raise-Create) matrix as follow.

\begin{tabular}{|c|c|}
\hline $\begin{array}{c}\text { Eliminate } \\
\text { - Reject (No Good) Product } \\
\text { - Over production } \\
\text { - quality trouble / loss-time } \\
\text { - claim \& complaint from } \\
\text { customer }\end{array}$ & $\begin{array}{c}\text { Raise } \\
\text { - increase "Brand Value" } \\
\text { - delivery speed } \\
\text { (on-time delivery) } \\
\text { - easy to get claim compensation } \\
\text { (after sales service) }\end{array}$ \\
\hline $\begin{array}{c}\text { Reduce } \\
\text { - Inventory / stock of Finish } \\
\text { - overall cost }\end{array}$ & $\begin{array}{l}\text { Create } \\
\text { - excessive quality }\end{array}$ \\
\hline
\end{tabular}

Figure 9. ECCR Matrix of Alpha Glass

(Author's compilation)

The above matrix will guide Alpha Glass on how to reduce the cost structure and increase buyer value and create new value and new needs for non-customer. Reducing cost can be observed from the actions of "Eliminate" and "Reduce", some of which are preventing defective products, avoiding over production that exceeds orders, preventing trouble or loss time, preventing claims and complaints from customers, minimizing inventory and reducing excessive quality. Some actions must be taken to increase buyer values are improving brand value, on-time delivery services, and handling claims and complaints in a fast and straightforward process. The new values to be created including innovative marketing by using a gadget or mobile applications for order process, creating a new product of lightweight glass and self-cleaning glass as well as glass integrated with 4G / 5G WiFi antenna.

All of the actions or strategies carried out by Alpha Glass, can be seen in the Alpha Glass's future Strategy Canvas, as in picture 6.

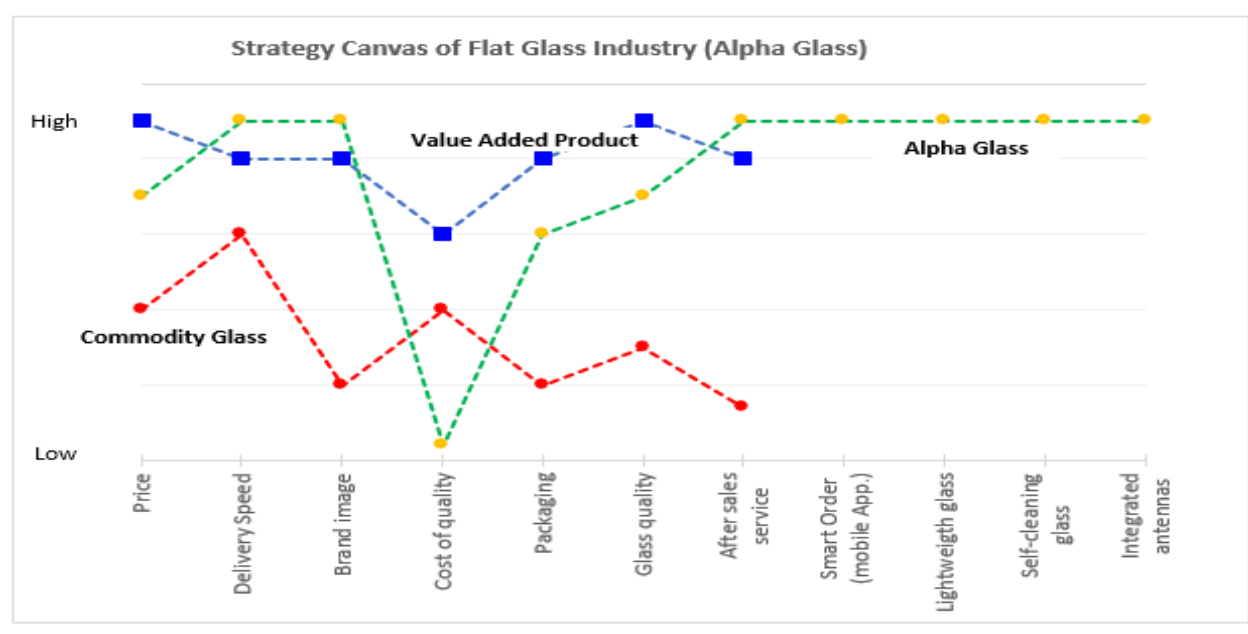

Figure 10. New Strategy Canvas of Alpha Glass

(source: Author's compilation) 


\section{Execution of the Blue Ocean Strategy}

After the Blue Ocean shift strategy framework is compiled in detail, step by step, the next step is to start conveying this new strategy to everyone at every level in the Alpha Glass organization. The purpose of this delivery is that all persons in the organization are involved in the changes, to give feedback to the company. Finally all people in the organization will ready to change. According to Kim \& Mauborgne (2017), this change process must be done by paying attention to three humanistic elements as follows. Atomization: is the process of solving challenges into small steps that can be done immediately.

1. First-hand discovery is the process of allowing people to discover their own needs for change.

2. A fair process is a process that involves all employees in building a collective will to face change and take risks in the blue ocean by fostering mutual respect and mutual trust.

The most recent step in shifting the Blue Ocean is a process of change that involves all leaders and employees and other parties involved, such as Business Partners, outsourcing. They are encouraged to discover their own needs for change and build collective trust, optimism, and creativity in shifting the blue ocean.

\section{Conclusion}

The flat glass industry is the upstream industry. Most of the products are semi-finished products that supply raw materials to the more downstream industries, namely the glass processing industry, such as for automotive glass or building glass. Thus, the domestic flat glass industry's existence as an upstream industry is essential and must be maintained because it will affect other industries that are more downstream. Therefore, the domestic glass industry must have the best strategy to win the competition against imported glass entry. One of the most relevant strategic concepts to deal with such competition is the value innovation strategy within the Blue Ocean shift framework.

In this study, the Blue Ocean shift that will be carried out at Alpha Glass is based on the Five Steps of the Blue Ocean Strategy Shift introduced by Kim \& Mauborgne (2017). Based on the analysis of the draft of the new strategy, the conclusions of this research are:

The "Blue Ocean Shift" strategy is more appropriate for Alpha Glass than the previous strategy because it is more systematic and more integrated.

In reality, in order to win the competition in the domestic flat glass market, the domestic flat glass industry, such as Alpha Glass, cannot just rely solely on the implementation of excellent strategy, but government support is also essential. Two essential things need government attention to protect the domestic flat glass industry against the imported glass from Chinese manufacturers. The first is protection through enforces the regulation of the Indonesian National Standard (SNI) for flat glass products. The foreign flat glass manufacturers and importer or distributors are obliged to fulfill the mandatory SNI requirements before entering the Indonesian market. The second is to reduce gas price for industry. Gas prices in Indonesia are highest compared to other countries in Southeast Asia (Idris, 2020). In the glass industry, the energy costs contribute around 30\% of the total cost so that the decline in gas prices will significantly affect production costs. Ultimately, the selling price can also be reduced so that it can compete with imported glass.

Excellent strategy, proper execution, and Government support, these three pillars will ensure the sustainability of the domestic flat glass industry amid the threat of imported glass from Chinese producers and have a significant impact on the National economy growth, especially the downstream industries. 


\section{References}

Adair, J. (2009). Effective Innovation: How to Stay Ahead of the Competition, New Revised Edition. Pan Books, Pan Macmillan Ltd.

AGC Group. (2016). On The Long term Group Strategy : Vision 2025, The AGC Group Magazine, 56.

Warta Ekonomi. (2019). Kemenperin Dorong Industri Kaca Tambah Kapasitas Terpasang. Retrieved from https://www.wartaekonomi.co.id/read256411/kemenperin-dorong-industri-kacatambah-kapasitas-terpasang.html

Aurik, J., Gillis J., \& Martin F. (2015). The History of Strategy and its Future Prospects, A. T. Kearney Inc. Retrieved from https://www.de.kearney.com/strategy-and-top-linetransformation/article?/a/the-history-of-strategy-and-its-future-prospects

Baharuddina, H., Syafei, W.A., Satoto, K.I. (2013). Pemodelan Sistem Informasi Untuk Mengukur Kualitas Kinerja Perguruan Tinggi dengan Pendekatan Balanced Scorecard dan Blue Ocean Strategy, Jurnal Sistem Informasi Bisnis,3(02).

Fleisher, C.S. \& Bensoussan, B.E. (2015). Business and Competitive Analysis: Effective Application of New and Classic Methods. New Jersey, Pearson Education, Inc. doi: 10.21456/vol3iss2pp74-81

Grant, R. M. (2016), Contemporary strategy analysis : text and cases edition, John Wiley and Sons; 9th Revised edition

Govindarajan, V., Matin, J., Shashikumar, VK. (2012), Get to Know Your Non-Customer. Harvard Business Review.

Gaynor, G.H. (2002). Innovation by Design: What It Takes to Keep Your Company on the Cutting Edge. New York : AMACOM.

Hansen, M.T. \& Birkinshaw, J. (2007). The Innovation Value Chain, Boston, Harvard Business Review.

Hendrianto, D., Kasim, A. (2017), Perumusan Blue Ocean Strategy PT Lippo General Insurance Tbk menjadi Leader di Industri Asuransi Indonesia, Jurnal Riset Perbankan Manajemen dan Akuntansi, 12). Indonesia, Sekolah Pscasarjana Institut Perbanas.

Idris, M. (2020, January 7th). RI Punya Gas Alam Melimpah tapi Harganya Lebih Murah di Singapura, Kompas.com, retrieved from https://money.kompas.com/read /2020/01/07/185500226/ri-punya-gas-alam-melimpah-tapi-harganya-lebih-murah-disingapura?page $=$ all

Kim, W.C. \& Mauborgne, R. (2005). Blue ocean strategy: how to create uncontested market space and make the competition irrelevant, Harvard Business School Publishing Corporation

Kim, W.C. \& Mauborgne, R. (2017), Blue Ocean Shift (Indonesian Edition : Pergeseran Samudra Biru). Indonesia, Gramedia Pustaka Utama.

Kibing Group. (2016). Retrieved from http://www.kibing-glass.com/en/investor.php

Kotler, P. and Kevin L.K. (2016). Marketing Management, 15th Edition New Jersey. Pearson Pretice Hall, Inc.

Leavy, B. (2018), "Value innovation and how to successfully incubate "blue ocean" initiatives", Strategy \& Leadership, 46(3), pp.10-20. United Kingdom, Emerald Group Publishing. Retrieved from: https://edisciplinas.usp.br/pluginfile.php/5063390/mod_resource/content/1/SL46i3Value\% 20innovationhow\%20to\%20successfully\%20incubate\%20blue\%20ocean\%20initiatives.pdf

McGrath, R.G. (2012). The End of Competitive Advantage: How to Keep Your Strategy Moving as Fast as Your Business. Brighton: Massachusetts, Harvard Bussiness Review Press

NSG Group. (2010). Pilkington and the Flat Glass Industry 2010. Japan: Tokyo, Nippon Sheet Glass Co., Ltd.

Porter, M.E. 1985. Competitive Advantage : Creating and Sustaining Superior Performance : with a new introduction. USA: New York, The Free Press. 
Pisano, G.P. (2015), You Need an Innovation Strategy, Harvard Business Review, June 2015 Issue. Retrieved from: https://hbr.org/2015/06/you-need-an-innovation-strategy

PT Asahimas Flat Glass, Tbk. (2015-2018), Annual Report of 2015,2018. Indonesia: Jakarta, PT Asahimas Flat Glass, Tbk. Retrieved from http://www.amfg.co.id/en/investor/investorinformation/annual-report

PT Mulia Industrindo, Tbk. (2015-2018), Annual Report of 2015,2018. Indonesia, PT Mulia Industrindo, Tbk. Retrieved from https://muliaindustrindo.com/id/info-investor/index

Rumelt, R.P. (2011). Good Strategy Bad Strategy: The Difference and Why It Matters. London: Profile Books.

Rajasekaran, R. (2016), Blue Oceans in Indian Sesame Oil Industry: A Case Analysis. Indiana: Bloomington, Indian University Press

Satell, G. (2017), Mapping Innovation: A Playbook for Navigating a Disruptive Age. New York, McGrawHill.

Sempels, C. \& Hoffmann, J. (2013), Sustainable Innovation Strategy : Creating Value in a World of Finite Resources. United Kingdom, Palgrave Macmillan.

Saputri, M.E., Mulyaningsih, H.D. (2016), Blue Ocean strategy for creating value innovation: A study over Kedai Digital in Yogyakarta, Indonesia, Journal of Administrative and Business Studies 2016, (1), pp. 14-20

Statista (2019). Retrieved from https://www.statista.com/statistics/697265/flat-glass-market-volumeworldwide-by-application

Utaminingsih, I.A. (2011), Rancangan Strategi Samudra Biru PT. SILKARGO Indonesia, Journal of Management and Business Review, 8(1), pp. 15-33

United Nations, Commodity in Trade [UN-Comtrade] (2019). Retieved from https://comtrade.un.org/Data

Xinyi Glass Holding Limited. (2016-2017), Annual Report of 2016 - 2017, retrieved from http://www.xinyiglass.com/en/index.php

Yin, R. K. (2018). Case study research and applications : design and methods, 6th edition. Los Angeles, SAGE Publication Inc. 